
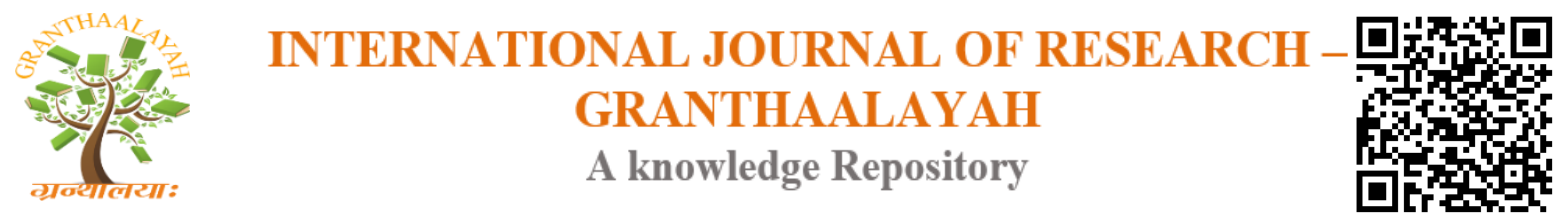

Social

\title{
SPECIAL EDUCATION PROVISION AND TEACHER PREPARATION IN UNIVERSITIES: A CASE OF KWAME NKRUMAH UNIVERSITY
}

\author{
Annie Penda ${ }^{1}$, Vincent Penda ${ }^{2}$ \\ ${ }^{1}$ Kwame Nkrumah University P.O. BOX 80404 Kabwe- Zambia \\ ${ }^{2}$ St Patrick girl's Secondary School Lusaka- Zambia
}

\begin{abstract}
This manuscript is a study on special education provision and teacher preparation in universities. The study aimed at establishing the special education provisions in universities, establishing how special teachers are prepared in universities and determine the requirement for learners with disabilities in order not to be left behind. The tools for data collection were the document study, interview schedule and the questionnaire. Data was analyzed using excel sheet and manually. The sample comprised of 30 masters students for special education programme at Kwame Nkrumah University. The findings were that special education provisions incorporated the special child's needs, national needs, international needs, the university needs, teachers' needs and technological needs. The study also found that, teachers were prepared by being equipped with knowledge and skills of special education. In order for learners with special needs not to be left behind it was discovered that they needed trained teachers in special education, infrastructure and curriculum modifications, teaching and learning materials and methods tailored to their needs, they needed schools, community, national, international and all stakeholders involvement in their education.
\end{abstract}

Keywords: Special Education; Provision; Teacher Preparation; Special Child; Involvement; Universities.

Cite This Article: Annie Penda, and Vincent Penda. (2018). "SPECIAL EDUCATION PROVISION AND TEACHER PREPARATION IN UNIVERSITIES: A CASE OF KWAME NKRUMAH UNIVERSITY." International Journal of Research - Granthaalayah, 6(10), 6-13. https://doi.org/10.29121/granthaalayah.v6.110.2018.1155.

\section{Introduction}

Education is a process of imparting knowledge and skills into the learner for survive. Special education fall under an umbrella of term of education. Special Education is the type of education that is offered to learners with disabilities in different continuum of services which includes special schools, an inclusive school, ordinary school, special education unit, resource room, specialized facilities which includes hospital unit, home based care and Cheshire homes. 
Inclusive schooling is central to the present thinking and it is the approach towards learning, which is termed as "inclusive learning ". Special Education fall under an umbrella term called the philosophy of inclusive education.

It is a move towards creating educational environments; concentrating on understanding better how learners with special needs learn so that they can be better helped to learn and be first and foremost seen as learners (Tomlinson, 1996).

A special teacher is a teacher who must have knowledge and skills of handling learners with disabilities. It is a kind of a teachers who should take trouble to study children in order to identify their needs and teach them effectively. Is a teacher who must understand the nature, behavior, the interest of children with special needs and takes into account the differences among them.

\section{Brief History}

Using the document study it was discovered that, Kwame Nkrumah University (KNU) is a public teacher training education institution of learning under the ministry of Higher Education. Kwame Nkrumah University train educators for the nation in various courses with special education being included as needed by the nation. Training of teachers at Kwame Nkrumah University is carried out within the goals and general policy framework of the firm or agency which is the Ministry of Higher Education. The university has a vision of "becoming a leading university in the provision of quality higher education at the national and international level". It has contributed to teacher preparation and production.

Kwame Nkrumah University initially was called Kabwe Teachers' College and was opened in 1967. In 1971, it was renamed as Nkrumah Teachers' College in honour of Dr. Kwame Nkrumah, the first President of the Republic of Ghana. In November 2013 it was pronounced as a University. From 2009, the University started offering a four year Bachelor of Education (B.Ed) degree program through full-time, part-time and distance-learning modes. In 2010 the first degree programme for special education started being offered on distance and full-time learning modes. Nkrumah has been producing special teachers for the past four years. In 2017 a master's program commenced with 35 students. The second group of master's students also began in this year 2018 on 26 August. Nkrumah is the first institute to roll out special education content to all students even to those not specializing in special education through the course called introduction to special education with a course code as EDU 110.

\section{Objectives of the Study}

The following objectives guided this study

1) To establish the special education provisions in universities

2) To establish how special teachers are prepared in universities.

3) To determine the requirement for learners with disabilities in order not to be left behind.

\section{Research Questions of the Study}

The following objectives guided this study

1) What are the special education provisions in universities? 
2) How are special teachers prepared in universities?

3) What are the requirements for learners with disabilities in order not to be left behind?

\section{Statement of the Problem}

Kwame Nkrumah University has been involved in teacher preparation and production for the nation From 2009, the university started offering a four year Bachelor of Education (B.Ed) degree program through full-time, part-time and distance-learning modes in various courses with special education being included. There has been no information on special education provision, how teachers are prepared and what is required for learners with disabilities not to be left behind. Thus this study explored on the way teachers were prepared, special education given to them and requirement for learners with disabilities not to be left behind.

\section{Significance of the Study}

This study is significant because it provided information on special education teacher preparation and special education given to them as well as the requirement for learners with disabilities not to be left behind.

\section{Literature Review}

The literature will focus on special education provisions, teacher preparation and leaving no child behind.

Education is cardinal in a life of an individual it demands for commitment from those who are educators and those who are being educated. Special Education as one of branches of education is the type of education that is offered to learners with disabilities in different continuum of services. Currently inclusive education is central to the present thinking and it is the approach towards learning, which is termed as "inclusive learning ". Special Education fall under this umbrella term called the philosophy of inclusive education. Tomlinson, (1996). define inclusive education as a pairing of philosophy and teaching practices that allow each student to feel respected, confident and safe to learn and develop to his or her potential because it is based on the values and beliefs centered on the best interest of the student that which promotes social cohesion, belonging and active participation in learning and positive interaction with peers in the school community. The definition highlight the issues of good social sense of inclusive education which aim at overcoming segregation which teaches students with special needs to be fearful, ignorant and breeds prejudice. In this case inclusive education promotes that, all students need an education that helps them develop relationships and prepare them for life in the mainstream society.

During teacher preparation the courses are offered through face-to-face (traditional instruction) and open and distance learning (ODL) modes. The distance learning mode utilizes print as medium of instruction (Thomu \& Mkhaya, 2014). Students are offered a face-to-face four-year degree program with a major or minor in special education. With regard to teacher preparation, the policy outlined the following: The quality and effectiveness of an education system depends heavily on the quality of its teachers. They are the key persons in determining success in meeting the system's goals. The educational and personal well-being of children in schools hinges crucially on their [teachers] competence, commitment and resourcefulness. In view of this, the caliber of teachers and the teaching profession is of paramount importance. The Ministry of Education has the 
important task of sustaining the quality of individual teachers and of the profession as a whole. It would accomplish this by attracting suitable persons to take up teaching as a career, equipping them with initial professional education, and providing for their subsequent in-career development. Running parallel with this, it also has responsibility for rewarding their services and sustaining their morale through satisfactory terms and conditions of service (Educating Our Future, 1996, p. 104). For instance the Ministry of Education in collaborated with the University of Zambia and established national standards for teacher preparation programs, including special education teacher preparation (Longe \& Chiputa, 2003). This is because of being the first and well-developed mother university for the nation and this type of collaboration has spread to other universities in the country of which Kwame Nkrumah is one of the beneficiaries.

The level of special education teacher preparation are at degree and masters at Kwame Nkrumah University is as follows; To obtain a degree in special education, pre-service teachers complete four years of full-time study. Pre-service students major in special education and choose one teaching subject as a minor. To date, the special education program at Kwame Nkrumah has graduated students for four years, with the majority being employed by the Ministry of Education in various levels and capacities. Teachers holding teaching diplomas do apply to the university to pursue an in-service degree program. These teachers enroll as in-service distant students upon being granted paid study leave by the Ministry of Education. The in-service full-time students upon completing their first degree and being granted paid study leave by the Ministry Of Education do pursue a post graduate programmes as masters students as at now (Kwame Nkrumah University, 2017)

\section{Curriculum for Special Education Provision}

Currently, Kwame Nkrumah University employs the categorical approach to preparing special education teachers. The programme began with a focus which include courses on hearing impairment, visual impairment, learning disabilities, emotional and behavior disorders, albinism, physical and healthy disabilities, intellectual disability, learning disabilities, gifted and talented learners and communication disorder. However, worldwide developments in the field of special education and national needs prompted faculty in the department of special education at Nkrumah to undertake a critical review of the teacher preparation program in order to respond meaningfully to the challenges of educating learners with disabilities in the nation. Students' programs of study now include braille, sign language, neuropsychological assessment, inclusive education courses being added to the previous courses to strengthen student teachers' knowledge and counseling skills so that they are able to address the psycho-social challenges faced by learners with disabilities and students affected by HIV/AIDS, sickle cell, diabetes and so forth. Additionally, students are prepared to work with all students regardless of the disability.

Special education is equally offered in other countries which is very encouraging, for instance, in Zimbabwe it was reported that, trained teachers have elements of special needs education as part of their initial training (Dart, 2017),

\section{No Child Left Behind}

According to National Association of Protection and Advocacy Systems (2004) the purpose of the federal No Child Left Behind Act (NCLB) is "to ensure that all children have a fair, equal and significant opportunity to obtain a high-quality education. NAPAS (2004) stated that, it should be 
understood that, most children with disabilities are able to keep up with their peers academically for example they do take standardized assessments (tests) successfully some with and some without accommodations and/ or modifications. Further NAPAS (2004) discovered that the vast majority do not have disabilities that would prevent them from keeping up with their peers academically. This means they should be able to participate meaningfully in the regular standardized tests. For instance, some students may require approved modifications or accommodations in order to take the regular test. However, once these accommodations are provided, the students perform just like other students in their class. For example, a blind student might need a version of the test in Braille, but once the Braille version is provided, the student can participate at the same level as his classmates. Furthermore, NAPAS (2004) narrated that, nine of these categories do not include cognitive or intellectual impairments such as speech or language impairments, emotional disturbance, specific learning disabilities, hearing impairments, orthopedic impairments, other health impairments, visual impairments, deaf blindness, autism. In addition, NAPAS (2004) argued that, a great many students within the other four categories multiple disabilities, mental retardation, traumatic brain injury, and developmental delay are also able to function at grade level on the tests with or without approved modifications or accommodations. NAPAS (2004) concluded that if children with disabilities are excluded from the accountability system, they will become completely invisible, forgotten in the rush to meet the needs of students whose scores count. In order for the child not to be left behind there is need for them to be taking any option which fits them NAPAS (2004). For instance the option that of taking the regular assessment in the same manner as other students. The other option being that of taking the regular assessment with approved accommodations or modifications. For example, having a teacher read a test out loud to a blind student or providing the test in Braille. Yet another option is that of taking an alternate assessment that is based on the same achievement standards as the regular assessment. There is nothing that requires a state to have only one alternate assessment, and since students have varied and unique needs, it makes sense to consider having more than one alternate assessment. The last option is that of taking the alternate assessment based on different achievement standards such as a life skills rather than academic curriculum.

\section{Methodology}

The research used case study research design and used qualitative approach.

\section{Population and Sample Target}

The study targeted the population of masters students at Kwame Nkrumah University in the year 2018.The sample comprised of seventy nine (35) students who were doing special education master's programme at Kwame Nkrumah University in the year 2018.

\section{Data Collection Tools and Techniques}

Document study, questionnaire and observation schedule were used to collect data.

\section{Data analysis}

Data was analyzed using excel sheet and manually. 


\section{Findings}

\section{1) Teacher Preparation}

It was found that when preparing a special teacher the following were taken into account;

\section{Wider View}

On a wider view one respondent stated that, when special teachers are being prepared the needs of a learner were considered in order to meet them at the point of their needs. The other response was echoed that, during teacher preparation institutional needs were considered such as the mission, and vision. Another respondent stated that, national needs were included when preparing special teachers such as the need to train special teacher for the secondary school or primary school. Then another response was that international needs were also cardinal as special teachers were being prepared in order to implement some policies at international level such as education for all which mushroomed from Salamanca statement and framework for action on special needs education during the world conference on special needs education with emphasis on access and quality in Spain from 7- 10 June 1994. Furthermore another response was that, technology were part and parcel of training programme when preparing special teachers.

\section{Direct needs}

On the direct need, one student voiced that, the training package for special teachers would need the component of special education academic knowledge in order for them to understand learners with disabilities. Another response was that, in order to perform well in the field those who are training to handle learners with disabilities needed special education academic skills.

\section{2) Special Education Provision}

In response to what Kwame Nkrumah University provided in terms of the curriculum for special education when preparing special teachers was reported that the institute offered the courses which had the following special education academic skills and knowledge to the undergraduate and post graduate students.

\section{Undergraduate Training}

One respondent revealed that, the university offered Knowledge about all the different disabilities under special education. The other response was that the university offered knowledge about identification, assessment and intervention of persons with disabilities. Another respondent reported that, the university offered technology, sign language and braille writing and reading skills to trainee teachers. Skills on how to handle learners with different disabilities were reported having been offered to trainee teachers at the university. Furthermore it was narrated that, counseling skills that would be used when dealing with children with different disabilities were offered to students training as special teachers at the university. The study revealed through one respondent that, appropriate teaching methods to be used when teaching different types of disabilities were offered. The study discovered through a response from one student that the university empowered students for special education programme with neuropsychological knowledge of assessment of learners with learning disabilities. The skills on how to handle learners with emotional and behavioral disorder were being offered to students for special education as reported by one respondent. 


\section{Postgraduate Level}

At masters level the university offered or empower students with the skills and knowledge counseling, neuropsychological assessment inclusive education with a particular focus on academic inclusion as echoed by one respondent. It was narrated by one respondent that, research knowledge and skills were offered to students in order to help address various problems under special education from research point of view.

\section{3) No Child to be Left Behind}

The involvement of the university in the provision of special education and teacher preparation required the following in order not to leave any child behind as reported by different respondents. The response from one respondent was that, the child with special needs would need a modified curriculum, physical environment, appropriate and necessary teaching and learning materials equipment and methods to aid learning. The other point of view from another respondent was that, the learner would need remedial work, parents and teachers working together for the benefit of a child. Then the response from one student was that, learners with disabilities need good relationship with the parents, teachers and fellow pupils. Provision of assistive technology such as hearing aids was reported as another requirement if a child with disabilities would not be left behind as stated by one respondent. It was stated by one respondent that conducive and userfriendly learning environment and co-teaching are requirements and beneficial to learners with disabilities in order for them to learn better. The response from a student revealed that, "inclusive education mode is needed to some learners with disabilities which are mild and moderate and those whose disabilities are severe or profound need special education mode because they can fit and learn better in those modes and receive quality education".

The child would need the flexible and enlightened administrators, deliberate and flexible policy, upgrading of teachers as reported by one respondent. The key people required to take responsibility with active involvement as revealed through one student were the "government, ministry of education, parents, schools, school administrators, teachers trained or untrained in the field of special education, the pupil himself or herself and other fellow pupils, policy makers and implementer, trainers in various universities and colleges, examiners, curriculum specialists, human rights personnel, , communities, churches, non-governmental organizations, curriculum specialists in short all stakeholders". The other response was that there was need to train special education teachers, need for accessibility to education and financial resources in order to help those who are faced with financial challenges.

\section{Discussion of Findings}

\section{Teacher Preparation}

The study discovered that, when preparing teachers who would later save learners with disabilities the following needs were taken into account needs of learners, institutional needs, national needs, international needs technological needs and trainee teachers' needs. The discoveries of the current study was similar to the findings of Longe and Chiputa, (2003) who reported that the Ministry of Education in collaboration with the University of Zambia established national standards for teacher preparation programs, including special education teacher preparation. However the current study mentioned various needs being taken into account when teachers were being prepared. 
The researcher's point of view basing on these empirical findings was that, the needs taken into account helps trainee teachers to meet the local and global advancements.

\section{Special Education Provision}

The study unveiled that, the curriculum for special education provision comprised of academic knowledge and skills on various disabilities which were offered to undergraduate trainee teachers while postgraduate trainee teachers were offered academic knowledge and skills as well as research skills. Unlike in Zimbabwe were it was reported that, trained teachers now have elements of special needs education as part of their initial training (Dart, 2017) in which the curriculum being offered was not highlighted.

The understanding of a researcher basing on these findings was that the skills and knowledge being provided to trainee teachers determines how effective special education services would be delivered to learners with disabilities in various institutions were they receive their education.

\section{No Child Left Behind}

The study found that, involvement of the university in the provision of special education and teacher preparation is part of the response to leaving no child behind as reported by different respondents. It was also revealed that active involvement all stakeholders was necessary such as the "government, ministry of education, parents, schools, school administrators, teachers trained or untrained in the field of special education, the pupil himself or herself and other fellow pupils, policy makers and implementer, trainers in various universities and colleges, examiners, curriculum specialists, human rights personnel, communities, churches, non-governmental organizations, curriculum specialists ". The findings were part of the fulfillment of the National Association of Protection and Advocacy Systems (2004) who stated that, the purpose of the federal No Child Left Behind Act (NCLB) is " to ensure that all children have a fair, equal and significant opportunity to obtain a high-quality education.

\section{References}

[1] Dart, G. (2007). Provision for Learners with Special Educational Needs in Botswana;

[2] A Situational Analysis. International journal of special education. Vol 22 issue 2 pp-56- 66.

[3] Kwame Nkrumah U niversity. (2017). Innovation, Teaching, Learning and Research for Sustainable Development: Teaching for Excellence, Fourt graduation ceremony

[4] Longe, R. \& Chiputa, S. S. (2003). National capacity building of lead teacher training institutions: a mission to Zambia. Lusaka, Zambia: UNESCO

[5] Ministry of Education, Zambia (MOE, 1996). Educating Our Future: National Policy on Education. Lusaka: Government Printers

[6] National Association of Protection and Advocacy Systems (2018). Children with disabilities Under No child Left Behind: Myths and Realities. http://www.papas.org Accessed on 26/09/18.

[7] Thomu, L. \& Mkhaya, L. (2014). Montfort Special Needs Education (SNE) College. Unpublished Report. Chiradzulu, Malawi: Montfort SNE College

*Corresponding author.

E-mail address: anniependa@yahoo.com/vinhel23@yahoo.com 